\title{
ADMINISTRATIVE MACHINERY AND PROCEDURES FOR RENEGOTIATION
}

\author{
LT. Cor. Paud B. Boyd*
}

\section{Administrative Authority and Delegation $\dagger$}

The Renegotiation Act, ${ }^{1}$ effective April 28 , 1942, as originally enacted, authorized and directed the Secretary of War, the Secretary of the Navy, and the Chairman of the Maritime Commission, whenever in their opinion excessive profits have been realized, or are likely to be realized, from contracts with those agencies or from any subcontract thereunder, to require the contractor or subcontractor to renegotiate the contract price, with some exceptions. Provision was also made for withholding and recovering payments, for the insertion of renegotiation clauses in contracts, exclusion of certain costs, and related matters. Subsequently, the scope of the statute was broadened to include contracts and subcontracts of other agencies ${ }^{2}$ procuring war materiel and services: the War Shipping Administration (by Executive Order of September 16, 1942); the Treasury Department (by Revenue Act of 1942, October 2I, I942); four subsidiaries of Reconstruction Finance Corporation, namely, Defense Plant Corporation, Metals Reserve Company, Defense Supplies Corporation, and Rubber Reserve Company (amendment of July I, I943). Renegotiation of contracts or subcontracts of the Treasury Department and these other Governmental Agencies was made retroactive to April 28, I942. The authority for renegotiation and redelegation was accordingly conferred on the War Shipping Administrator, the Secretary of the Treasury, and Board of Directors of each of the four Reconstruction Finance Corporation subsidiaries.

* B.S.C., 1929, University of North Dakota. Member, War Department Price Adjustment Board. It. Colonel, General Staff Corps, A.U.S., graduate Command and General Staff School, Fort Leavenworth, Kansas. Former Executive Vice-President, Jewel Tea Co., Inc., Barrington, Illinois.

$\dagger$ While this article was in process of revision, the pending Revenue Bill of 1943 was introduced in Congress (Nov. 18, 1943), passed by the House, amended in Senate Committee, not yet introduced on Senate floor. The Bill, especially as amended by the Senate Finance Committee, contains provisions substantially affecting renegotiation in many respects. With respect to its possible effect upon renegotiation machinery and procedures, however, it is believed that its provisions are not such as to warrant specific discussion in this article. For a general discussion of the pending Bill the reader is referred to the concluding article in this symposium by Jules Abels. [ED.]

${ }^{1} 56$ StAr. 245, 4I U. S. C. A. note prec. \$1 (Supp. 1942). The original Act, Sec. 403 of the Sixth Supplemental National Defense Appropriations Act, 1942, approved April 28, 1942, has been since amended by: 56 STst. 798, 982, 50 U. S. C. A. §Irgr (Supp. July r943, Appendix) (Sec. 8or of the Revenue Act of 1942, approved October 2I, 1942); Pub. L. No. 108, 78th Cong., Ist Sess. (July I, 1943) (Sec. I of the Military Appropriations Act, I944); Pub. L. No. I49, 78th Cong., Ist Sess. (July 14, I943).

Supra note $x$. 
In conformance with the authority granted under the Act, as amended, delegations of authority were made for the proper administration of renegotiation. The Secretary of War has delegated all the authority and discretion conferred upon him under the Act to the Under Secretary of War. Reserving to himself the right to approve personally all unilateral determinations and to approve revisions in the policies, principles and procedures established for renegotiation, the Under Secretary has delegated all other authority and discretion conferred upon him to the Commanding General, Army Service Forces, for the administration of renegotiation within his command.

The Commanding General, Army Service Forces, has created the Renegotiation Division to function under the Director of Materiel and has established within the Division the War Department Price Adjustment Board to serve in an advisory capacity to the Director of the Division. He has conferred all powers delegated. to him under the statute to the Chairman of the Board, who serves also as Director of the Renegotiation Division. The Under Secretary conferred upon the Commanding General, Army Air Forces, authority for the administration and conduct of renegotiation within his command and directly delegated to the Chairman of the Board the responsibility for formulating policies and procedures for renegotiation in the Army Air Forces.

In accordance with these delegations of authority, the Commanding General, Army Service Forces, and Commanding General, Army Air Forces, have authorized and directed the Chief of the Army Technical Services and Assistant Chief of the Air Staff, Materiel, Maintenance and Distribution, to organize the nccessary Price Adjustment Sections for the conduct of renegotiation with contractors assigned to their commands. Authority has also been delegated to commanding generals of the United States Armed Forces in Alaska and outside the continental United States to conduct renegotiation with respect to contracts entered into pursuant to their respective authorities or assigned to them for administration.

The Secretary of Navy has conferred his authority for renegotiation on the Under Secretary of Navy who in turn has created the Navy Department Price Adjustment Board. In like manner Price Adjustment Boards have been created by the Chairman of the Maritime Commission, Secretary of the Treasury, and War Shipping Administrator. One board, called the Reconstruction Finance Corporation Price Adjustment Board, has been established by the Boards of Directors of the Defense Plant Corporation, Metals Reserve Company, Defense Supplies Corporation and Rubber Reserve Company.

General Administrative Machinery

War Department

Renegotiation Division and Price Adjustment Board. By means of delegations of authority from the Under Secretary of War through the Commanding General, 
Army Service Forces, for the Army Service Forces, and directly for the Army Air Forces, substantially all the authority conferred upon the Secretary of War under the Act has been delegated to the Chairman of the War Department Price Adjustment Board. The Chairman, accordingly, has been given full power to execute all voluntary agreements without review by higher administrative authority, while the right to approve personally all unilateral determinations and to revise the principles, policies and procedures for renegotiation is reserved to the Under Secretary of War.

The Chairman of the War Department Price Adjustment Board, subject to the limitations above set forth, has also been empowered to establish the policies, principles and procedures to be followed in renegotiation, assist the Technical Services and Army Air Forces in the organization of personnel and conduct of renegotiation, to review agreements and settlements concluded in the War Department and to exercise these powers through any designated member of the Board or through the staff of the Renegotiation Division.

As the result of these delegations, the War Department Price Adjustment Board, as the supervisory and coordinating agency for renegotiation within the War Department, functions through the Renegotiation Division in establishing, with the approval of the Under Secretary of War, principles, policies and procedures for renegotiation, in assigning cases to and assisting the Technical Services and Army Air Forces in their conduct of renegotiation, in the renegotiation of impasse cases and in the direct renegotiation of any company where unusual matters of policy, size of company or volume of contracts make such action advisable.

In the performance of these functions, the Renegotiation Division has been organized into the following Branches: Administrative and Control, Assignments, Renegotiation, Field Operations, Settlement, and Technical Information.

The Administrative and Control Branch has the responsibility for routine operation in the performance of the Division's functions and for evaluating the organization, methods and procedures of the Division. In addition, this Branch has charge of both military and civilian personnel, correlates the renegotiation activities of the various elements in the War Department, maintains statistical records and supervises the codification and dissemination of policies and procedures adopted.

With the consent of all the Governmental Departments and Agencies having renegotiation authority, the Assignment Branch of the Division is also known as the Departmental Assignment Board and handles assignments of all renegotiation cases among the renegotiation agencies. Functioning through three sections, the Examination, Assignments and Classification Sections, the duties of this Branch are to originate and stimulate the reporting of names of contractors subject to renegotiation, to examine available information for the purpose of either assigning contractors and subcontractors for renegotiation or screening out cases where excessive profits obviously do not exist, to classify contractors according to their products or services for assignment and to assign the contractors to the appropriate 
Price Adjustment Board, and within the War Department to the appropriate Technical Service or to the Army Air Forces.

Functions of the Renegotiation Branch of the Division are to assume responsibility for and promptly to conduct and complete renegotiation with the officers and representatives of the contracting companies assigned to the Renegotiation Division, recommending settlements in connection with these renegotiations.

The Field Operations Branch evaluates and checks the renegotiation activities of the Technical Services and Army Air Forces as to organization, procedure and personnel and assists the field sections in obtaining and training competent staffs.

The Settlement Branch of the Division has three sections devoted to final review and completion of renegotiation cases. The Financial Review Section has the duties of reviewing the financial aspects of all settlement agreements to determine their fairness, consistency with agreements in similar cases and their conformity to Board approved policies and procedures, and of recommending action thereon to the Chief of the Division and Board. The duties of the Legal Review Section of the Settlement Branch are to secure approval and execution of agreements embodying settlements by the Board, supervise the Financial Review Section and to secure approval by the Board of all agreements reached by the Renegotiation Division and recommended by the other Departments and Services. The Processing Section functions to secure execution on behalf of the Government of agreements receiving Board approval and to distribute to the proper parties executed and conformed copies of all such agreements.

The Technical Information Division establishes and maintains relations with the press, publications and trade associations for the dissemination of information concerning renegotiation and the policies and procedures related thereto, clears prepared papers or speeches through appropriate channels, encourages and develops opportunities for the public discussion of renegotiation by members of the Board and of Price Adjustment Sections of the Services.

The War Department Renegotiation Division and Price Adjustment Board are located in the Pentagon building in Washington. As of September I3, I943, the total personnel was 175 and of this number rog were stenographers and clerical assistants. Of the remaining staff of 66 specialists, there were 23 Board members, administrative officers and chiefs of divisions, I5 negotiators and corporate analysts, 5 handling legal matters, 5 cost analysts and statisticians and 18 specialists in miscellaneous categories. Forty-eight Division members were military officers and the remainder were civilian personnel.

Members of the Board are appointed by the Commanding General, Army Service Forces, with the approval of the Under Secretary of War and include the Chairman of the Board, the Vice Chairman, serving as Acting Chairman in the absence of the Chairman, two staff members of the Renegotiation Division, and a representative of the Chairman of the War Production Board. A member of the Navy Department Price Adjustment Board sits with the War Department Board. 
The members of the Board are business men with a long record of successful business experience. The various technical members of the staff have been chosen with regard for their particular qualifications and their past record in business. It is noteworthy that these technical representatives, which is also generally the case with the Price Adjustment personnel in the other Departments, in the Technical Services and in the Army Air Forces, are without exception from private business, considering their renegotiation work as a patriotic contribution during the present emergency and desiring to return to their private business activities when the work is completed.

Price Adjustment Sections. In accordance with the powers delegated to him, the Commanding General, Army Service Forces, redelegated to the Chief of each Technical Service the authority to create, with the advice of the Price Adjustment Board, the necessary Price Adjustment Sections to conduct the renegotiation of contractors assigned to each respective Service. Similar powers were conferred upon the Assistant Chief of the Air Staff, Materiel, Maintenance and Distribution, for the Army Air Forces, with respect to cases coming under its jurisdiction.

Accordingly there has been established a Price Adjustment Section in each of the Technical Services of the Army Service Forces and in the Army Air Forces. The Army Service Forces has Sections in the technical services of Chemical Warfare, Engineers, Ordnance, Quartermaster, Signal Corps, Surgeon General, and Transportation. With the exception of the Price Adjustment Section of Chemical Warfare, located in Baltimore, the main Sections of the other Technical Services are located in Washington. Headquarters for renegotiation in the Army Air Forces is shared by Washington and Wright Field, Dayton, Ohio. Wherever required, District Price Adjustment Sections have been established by the Services and the Army Air Forces at procurement centers, and this decentralization allows renegotiation to be conducted close to the location of the company involved.

The Price Adjustment Sections are required to observe the principles, policies and procedures prescribed by the Board, to establish and maintain appropriate procedures to assure uniformity of approach and result and to preserve adequate records showing the basis for settlement and the factors considered in determining the existence or non-existence of excessive profits. The basic principles and policies have been set forth in a joint statement of the War, Navy and Treasury Departments and Maritime Commission published on March 3I, r943. The War Department Manual for Renegotiation ${ }^{3}$ embracing this information as well as detailed instructions on all matters relating to organization procedures and policies, has been available since August 15, 1943, for the guidance of the Sections. While the conduct of renegotiation conforms generally to the patterns and standards prescribed, the machinery and procedures developed have necessarily been adapted to the peculiar needs and conditions existing in each Service.

${ }^{3}$ While this Manual has been reserved for the internal use of the agencies engaged in renegotiation, it is anticipated that the new Joint Renegotiation Manual will be available to war contractors and the public in the near future. 
Authority has been delegated to the Chief of each Service to execute renegotiation agreements for all the Departments, without further review or approval, where a contractor's total sales, both renegotiable and non-renegotiable, do not exceed $\$ 10,000,000$ for the fiscal year under review. The Chief of each Service may delegate within his organization similar authority to conclude agreements where total sales are not over $\$ 5,000,000$. All other agreements reached are subject to review by the Board and approval by the Under Secretary of War on behalf of the Government.

On September 13, 1943, the personnel of the Price Adjustment Sections in both the Army Service Forces and Army Air Forces totaled 1,644, with $95^{\circ}$ serving as technical specialists and the balance of 694 as clerical aids. The technical staff embraced 156 in the category of local board members and chiefs of offices and sections, $3^{\text {T2 }}$ negotiators and corporate analysts, 35 performing legal functions, 356 cost analysts and statisticians and $9 r$ financial reviewers and other specialists. Military personnel comprised 224 and civilian personnel $r, 420$ of the entire force.

Before continuing with a discussion of the particular machinery and procedures within the different Departments, Agencies, and Services, a broad survey of general procedures is indicated at this point.

\section{Gengral Procedures ${ }^{4}$}

\section{Assignment}

All assignments for renegotiation, on behalf of all the interested Departments, are made by the Clearance and Assignment Officer of the Departmental Price Adjustment Boards operating through the medium of the Assignment Branch of the Renegotiating Division of the War Department. The policy, as far as practicable, is to assign all contractors producing the same or similar products to the same Department or Service. Accordingly a particular contractor will ordinarily be assigned to the Department or Service having the principal interest in the type of products and services furnished by the contractor even though that Department or Service may not have a predominant interest in the contracts being currently performed by the particular contractor.

A contractor must be officially assigned by this Branch before renegotiation of his excessive profits may be initiated. Any Department or Service may request immediate assignment of any case without assembling preliminary information whenever it deems such action necessary or appropriate. The Services are required to secure information from their contracting officers as an aid to the Assignment Branch in recommending contractors for renegotiation, especially in cases where scandalous conditions exist, where practices exist which might be a discredit to the War Department or the contractor, where profits reflect high costs by comparative standards, and where excessive profits are known to exist.

\footnotetext{
"This discussion is devoted primarily to the procedures generally followed in the War Department's renegotiation.
} 
It is the duty of the Assignment Branch, on behalf of all the Departments and Services, to identify companies which may be subject to renegotiation. For this purpose information is obtained from all available sources. Under authority con: ferred by the Renegotiation Act, and by arrangement with the Bureau of Internal Revenue, summary transcripts of income tax returns, containing pertinent information relating to sales, profits and renegotiable business, are made available to this Branch for review.

Where it appears that excessive profits may have been realized, the form letter of preliminary inquiry, requesting information necessary to determine whether or not assignment should be made, is forwarded to the company.$^{\mathrm{a}}$ Accompanying this letter is the appropriate report form for either a supply. or construction contractor, a copy of the statute and a statement of non-applicability under the act for use wherever justified. Upon return of this information, the facts of the case are reviewed independently by two analysts, one of whom is usually a representative of the Department to which the contractor would ordinarily be assigned. Where renegotiation is in order, the case is immediately assigned to the proper Department or Service. Assignment is made without recourse to the letter of preliminary inquiry where available information clearly indicates the necessity for renegotiation and the particular agency to handle the proceedings.

Assignment of a case to a particular Department or Service is final for the fiscal year under review, unless subsequent developments indicate the advisability or necessity of reassignment to another Department or Service or the cancellation of the assignment. In general, no reassignment is made after conferences with the company have commenced. Ordinarily the Board authorizes reassignment of a

\footnotetext{
da The information requested of a supply contractor in anticipation of the renegotiation of his 1942 business included complete financial data (balance sheets and related income and surplus statements, including available detailed audit reports of his independent public accountants) for his fiscal years I94X and 1942 and the elapsed portion of 1943 ; the nature of his prewar business, the extent and date of conversion to war work and a description of peacetime and wartime products; affiliation with other concerns, including names and addresses of affliates, volume and extent of affiliation or relationship, character of affiliates' business and an expression of opinion regarding the desirability of treating the contractor and his affiliates on a consolidated basis for purposes of overall renegotiation; a segregation of sales between renegotiable and non-renegotiable business and a further analysis of renegotiable sales into direct (based on prime contracts or purchase orders) and indirect (based on subcontracts, purchase orders, etc.); an estimate of the percentage of total renegotiable business (both direct and indirect) ultimately billed to each of the Departments and Army services; compensation in excess of $\$ 10,000$ paid to officers and employees during 1940 and subsequently; government assistance at the end of the latest complete fiscal year, including " $V$ " Loans and facilities furnished or financed by the Government; a reconciliation of financial data submitted with those reported for Federal tax purposes, and an explanation of charges for post-war conversion, inventory shrinkage or other contingencies.

Construction contractors were requested to furnish less of the overall financial data asked of supply contractors but more specific contract information, such as the contract number of each contract and subcontract; the type of each contract (advertised or negotiated; lump sum, unit price or cost-plus-a-fixedfee; prime or subcontract; architect-engineer, construction or combination); the name of the Department or Agency with which each prime contract was made; the name of the prime contractor and Department or Agency with which each subcontract was made; contract price, including amendments, and for cost-plus-a-fixed-fee contracts, a separation of the price into estimated cost, fee and final cost; a brief description of the nature and location of the work; the approximate per cent of work subcontracted to others; and a classified summary of profit and loss on all contracts and subcontracts completed during the latest complete fiscal year.
} 
case if it appears that the contractor should be renegotiated concurrently or on a consolidated basis with another contractor already assigned to another Department or Service or if the nature of its products or its corporate relationships or similar considerations so require. The Board will cancel an assignment where a contractor is exempt under the act or where it clearly appears that excessive profits have not been realized.

\section{Renegotiation}

While cases may be assigned directly to the War Department Price Adjustment Board for renegotiation, the great majority of War Department renegotiations are handled by the Price Adjustment Sections of the Technical Services and Army Air Forces. The Services generally follow identical patterns of procedure in conducting renegotiations.

The initial step in renegotiation proceedings is the assignment of a case to a Section of one of the Services, and with the reassignment of the case to a negotiator in the Section for handling. As far as possible, a negotiator is assigned contractors engaged in similar industries or types of production in order to allow him to become specialized in a given field. A negotiator is not assigned a company in which he is directly or indirectly interested.

The original assignment from the Board indicates the other Departments or Services which are interested and which have been notified of the assignment, and it is the duty of the negotiator to advise any other Department or Service which is later found to have an interest in the case. As agreements made by a Department or Service with a contractor assigned to it are binding upon all other Departments and Services, representatives of any interested Department or Service may confer with the negotiator and acquaint him with all information necessary to a proper determination in the case. Unless specifically requested, however, no other Service or Department is obligated to furnish information, and similarly the negotiator is not obliged to furnish notice of meetings or other information to an interested Department or Service, except in the case of the Navy Department which has requested the renegotiating Service to submit copies of the minutes of all meetings relating to a case in which it has an interest.

The negotiator is responsible for the conduct of renegotiation proceedings and is assisted by a cost analyst. The cost analyst is responsible for assembling and checking the accounting information required and for advising on the technical financial matters involved in the renegotiation. Necessary information may be obtained by correspondence, conference, visit to the contractor's office or other available method. There is now available the Contractor's Information Form for the convenience and guidance of the contractor in furnishing the desired information.

It is the policy to collect all possible information prior to the first meeting with the contractor so that actual meetings may be devoted to evaluating these data. In this way an agreement may be reached with the minimum of delay and incon- 
venience to the contractor. In assembling and preparing the information every effort is made to prevent duplication of work and delay. Reports of independent public accountants are obtained wherever available and the cost analyst refrains from auditing the contractor's books or examining in detail the methods of segregating renegotiable sales unless exceptional conditions require this action. All information is prepared for the dual purpose of conducting the renegotiation and of providing material, upon request, to aid procurement officers in establishing sound contract prices.

Meetings with contractors are ordinarily held in the office of the Section conducting the renegotiation and are attended by at least two Government representatives, including the negotiator and cost analyst. Whenever personnel allows, panels for handling conferences are established. While an interested Department or Service may have a representative present, every effort is made to hold down the number of Government representatives at any meeting and usually only the negotiating Service is represented.

At the first meeting with the contractor, the negotiator explains the objects of the renegotiation statute and its underlying philosophy and policies. If the necessary information has not already been obtained, the negotiator explains what additional data are required and stresses the value of submitting the information promptly and in good order to simplify and expedite the renegotiation procedure. Following the first conference the negotiator prepares the minutes of the meeting and the cost analyst, if he has not already done so, submits his report in conformance with a prescribed form. Subsequent meetings, if necessary, in the pattern outlined above, are conducted in an effort to evaluate all aspects of the case and arrive at an agreement as to the amount, if any, of excessive profits involved. Field Sections operate in similar manner and maintain constant contact with the main Section offices both for the assistance that may be rendered and for the purpose of achieving uniformity in result.

\section{Agreements}

Subsection (c) (4) of the Act provides that the proper authority may make final or other agreements with a contractor for the elimination of excessive profits and for the discharge of any liability thereunder, and provides that any such agreement shall be final and conclusive according to its terms. There are three general types of agreements: the interim agreement, the final agreement and the clearance notice.

Interim agreements are used when there is a temporary adjustment pending further consideration of the information submitted or to be submitted and where it is contemplated that there will be further renegotiations before a final settlement is reached. Such an agreement may be in any form provided it states that the agreement is not final, does not prejudice subsequent determination in the case, and that no amount previously paid to the Government as a result of any renegotiation shall be refunded as the result of any subsequent renegotiation. 
Final agreements are used to provide for clearance from liability under the act whenever a contractor has negotiated in good faith for a specified period and agreed to eliminate excessive profits for that period. Such agreements must be related to the statute and follow the general structure of the standard form of agreement. Two forms are available, one to be used when the fiscal year under review has closed and actual figures are available and the other where the year is still under review and actual figures are not yet available. These final agreements are subject to reopening by the Under Secretary of War only in the case of fraud or in the event that actual figures are at material variance with estimated figures which may have been used.

The final agreement contains a complete statement of all important factors involved in the settlement including the amount agreed upon as representing the aggregate excessive profits realized or likely to be realized from the contracts or subcontracts for the fiscal period under review, specific information concerning the contracts or subcontracts affected showing the price reductions called for under future deliveries, a full description of the dates and amounts and method of payment of all cash refunds, and if relating to a past period for which Federal tax returns have been filed, a statement of the tax credit to which the contractor is entitled under Section 3806 of the Internal Revenue Code.

Clearance notices follow two standard forms, one to be used when the contracts of the Reconstruction Finance subsidiaries are included in the renegotiable business considered and the other in all cases in which the determination is made prior to the inclusion of these contracts.

All agreements are signed on behalf of the contractor by the owner, a partner or an authorized officer and in the case of a corporation are accompanied by an attested copy of a resolution of the Board of Directors authorizing its execution. Dependent upon the signing authority as delegated, the agreement or clearance notice will be approved and executed on behalf of the Government by the Service which conducted the renegotiation or submitted to the Board for approval and for execution by or on behalf of the Under Secretary of War, acting for all the interested Departments and Agencies of the Government.

In addition to the preparation of the formal agreement or clearance notice, it is required that each Section prepare also a report of settlement explaining and justifying the terms of the settlement and containing sufficient information to provide both a basis for approval by the authorities whose approval is required and a permanent record for future justification of the decision reached. There are two standard forms, the short form used in case of clearances and where excessive profits agreed upon do not exceed a certain stipulated and relatively low percentage return on volume of renegotiable business and the long form used in all other cases. Each standard report is divided into two parts consisting of a narrative summary in topical form and financial data in tabular form, with the narrative portion developing all general information relating to the background of the case, 
business of the contractor, price and production record, governmental financial assistance, and including a clear, factual and comprehensive statement of all important financial matters, and the recommendations with respect to the amount, basis and functioning of the settlement.

Upon the approval and execution of renegotiation agreements, a definite pattern of procedure is followed in administering the terms of the agreements. In both cases when a Service has conducted renegotiations and concluded the agreement and where the Board has performed these functions, the administration of the agreement is handled by the Fiscal Branch of the Service having the predominance of interest in the case. It is the duty of the Fiscal Branch to verify compliance by the contractor with all the provisions of the agreement and to see that all required payments are made. All checks submitted by the contractor in payment of refunds are forwarded to the nearest Fiscal Office involved, which in turn covers the payment immediately into the Treasury as Miscellaneous Receipts for credit to the account of "Excessive Profits on Renegotiation."

\section{Refunds and Price Reductions}

The act authorizes the elimination of any excessive profits realized or likely to be realized by reductions in the contract price, by withholding from amounts otherwise due to the contractor or subcontractor any amount of such excessive profits, by directing a contractor to withhold such amounts from the subcontractor, and by recovery from the contractor or subcontractor, through repayment, credit or suit, of excessive profits actually paid to him.

In renegotiation for a prior fiscal period the elimination of excessive profits will usually be made in the form of a refund, and this refund may be made by the contractor in a single payment or in installments. Ordinarily, when excessive profits are eliminated by installment payments, the final installment must be made not later than the end of the fiscal year following that to which the renegotiation relates and the installments must be arranged so that total payments required prior to each quarterly tax payment date are at least equal to the Federal income and excess profits taxes which would have been paid on the excessive profits eliminated. In cases of undue hardship, certain exceptions may be permitted for limited extensions of time.

Whenever statutory renegotiation for a past period reveals that the contractor's current prices are yielding excessive profits, it is the obligation of the interested Price Adjustment Section to obtain or provide for price reductions on future deliveries under the renegotiated contracts and subcontracts. Only in this manner can the renegotiating agency complete its duty in eliminating profits likely to be realized. Determination of the price reductions to be made are dependent upon the same factors in the main as were originally considered in the renegotiation dealings.

Various methods are used in effecting price reductions on future deliveries. Where a relatively few large contracts represent a substantial portion of the con- 
tractor's business and these contracts are with the Service conducting the renegotiation, the unit prices may be reduced directly in the renegotiation proceedings, and provided for in the agreement. In the case where a relatively small number of products make up a predominant portion of a contractor's business, the prices of the products may be adjusted to a fair basis and the facts included in the renegotiation agreement.

Where it is not feasible to adjust the individual unit price, a flat percentage reduction on all renegotiable sales may be required or the contractor may be obliged to agree to make reductions on outstanding contracts in a minimum dollar amount. Where it is necessary to close a renegotiation promptly and time does not permit the proper determination of price reductions, the renegotiation agreement may provide that the contractor agrees promptly to investigate the costs involved and as rapidly as practicable effect appropriate price reductions. Actual adjustment in the contract prices currently is required and failure to comply is taken into consideration in subsequent renegotiations.

In effecting price reductions, consideration is given to the contractor's statements and estimates on the costs involved, to all available information obtained through renegotiation or otherwise and to the recommendations and facts presented by the procurement staff. Provisions in the agreement for reductions in prices must state clearly that such action does not serve as a clearance for those prices or to preclude subsequent renegotiation of the contract prices.

\section{Impasse}

Refusal to Submit Information. Two possible situations may interfere with renegotiation procedure. Either a contractor may refuse to submit the required information or be unwilling to agree to a settlement considered fair by those conducting the renegotiation. In covering the first situation, the Renegotiation Act provides that the services of the Bureau of Internal Revenue shall be available for the purposes of making examinations and determinations with respect to excessive profits and further that the Secretary of each Department shall have the right to demand of any contractor who holds contracts subject to renegotiation, under penalty of law, statements of actual costs of production and such other financial information as may be required. Title XIII of the Second War Powers Act, I942, also gives the Government the right to inspect and audit the books of any contractor holding an order placed in furtherance of the war effort.

Unilateral Determination. Subsection (a) (3) of the Renegotiation Act provides that the term "renegotiation" includes the refixing of the contract price by the Secretary of the interested Department. Giving recognition to cases where contractors may seek to postpone or delay renegotiation in the expectation and hope of relief from Congress, the Under Secretaries of War and Navy in a joint statement of July 23, x943, stated that the several Departments, being under obligation to continue renegotiation under existing law, should refer such cases immediately to 
the Under Secretary of War or Navy for final determination of excessive profits realized or likely to be realized by the contractor under his contracts.

If, after reasonable effort, the Service is unable to obtain an agreement by the contractor to a settlement considered fair by the Service, the impasse case is submitted promptly to the War Department Price Adjustment Board. If the Board is unable to come to an agreement with the contractor, the case is finally referred to the Under Secretary of War for appropriate action under the Act.

In the event of the necessity for a unilateral determination, the Under Secretary first makes a final determination of the amount of excessive profits for the fiscal year involved; secondly, may make such supplemental audits and investigations as might be required to afford a basis for final determination of the amount of the excessive profits realized since that time; thirdly, may effect a reduction of prices on all outstanding continuing contracts to the extent necessary to eliminate excessive profits likely to be realized in the future; and finally may recover any excessive profits determined to have been realized by withholding sums due on his prime contracts and, if the situation called for such action, may direct his prime contractors to withhold sums due on their subcontracts until all excessive profits had been eliminated.

The War Department has taken the position that it will employ every authorized method of eliminating excessive profits. The contractor, subjected to a unilateral determination, is entitled to obtain a judicial review of the War Department's action, if he wishes to do so, by suing for the recovery of any amounts withheld.

Right of Review. While it is clear that a contractor or subcontractor who concludes a voluntary agreement based upon renegotiation does not have access to the courts for relief, it is equally clear that a contractor or subcontractor subject to a unilateral determination in a renegotiation settlement does have a right to judicial review.

The statutory history of the Renegotiation Act shows that such judicial review was contemplated. Section 403 (c) (3) of the statute, as originally introduced into the Senate, prohibited suits to recover from the United States any amount withheld from a contractor in renegotiation. As a result of objections raised, no such provision became law. The Congressional Record reveals that the lawmakers considered such a provision unfair. ${ }^{5}$

Controlling judicial principles and decisions are authority for the right to judicial review in the event of a unilateral determination. The right of judicial review does not rest upon any prescribed statutory grant. As a consequence of these factors, it is clear that Congress intended to permit judicial review with respect to unilateral determinations under the statute and that under well-settled principles of law a right to such review exists."

${ }^{5} 88$ Cong. Rec., April 23, 1943, at 3765-6.

-A concise legal brief in support of the conclusion that "it cannot be disputed, first, that Congress intended to accord judicial review under the renegotiation statute, and second, that under well-settled 


\section{Coordination}

Ever since the passage of the Renegotiation Act, there has been a deliberate and concerted effort to coordinate the policies and procedures of renegotiation between and within the different interested agencies, of which the recent establishment of the Joint Price Adjustment Board was the logical culminating development. Even before this development, the Price Adjustment Boards of the various agencies have acted in the formulation of policies and procedures in renegotiation and price adjustment in close relationship with the boards of the other representative agencies, to the end that a consistent approach and a consistent uniformity in renegotiation might be maintained. Although there was naturally at the outset some divergence in the policies of the Boards, the elements of difference have in every important respect been fully reconciled. The Boards are now operating under the declaration of Purposes, Principles, Policies and Interpretations embodied in a joint statement, published March 3x, I943, of the War, Navy and Treasury Departments and Maritime Commission, and in conformance with the War Department Manual for Renegotiation issued on August I5, I943.

Even before the creation of the Joint Board, uniformity among the Boards was maintained through a constant liaison and through joint meetings of the chairmen of the Boards, and of the Under Secretaries of War and Navy with representatives of the Price Adjustment Boards, by attendance at meetings of each of the Departmental Boards of the representative of the Chairman of the War Production Board as coordinating member at the meetings of each of the Boards and by the usual attendance of a member of the Navy Board at the meetings of the War Department Board.

Under date of September 24, I943, a Joint Price Adjustment Board was created by joint action of the Secretaries to which they delegated authority and discretion as follows:

(a) To formulate and adopt statements of purposes, principles, policies, and interpretations under the statute which shall be binding on the Departments.

(b) To define, interpret and apply by joint regulation the exemption specified by the statute relating to the product of a mine, oil or gas well or other mineral or natural deposit or timber.

(c) To exempt from some or all of the provisions of the statute general classes or types of contracts, and to formulate standards for the exemption of such contracts.

(d) To determine whether any contractor shall be required to renegotiate for any fiscal period the contract price under some or all of his contracts subject to renegotiation under the statute.

(e) To assign any contractor to any Department for determination whether excessive profits have been or are likely to be realized from some or all of its contracts subject to renegotiation under the statute.

(f) To prescribe by joint regulation the form and details of the financial statements contractors may file, and the form, time and manner of giving the notice to which they

principles of law a right to judicial review exists under such statute," see Hearings before the Committee on Naval Affairs purstrant to H. Res. 30, 78th Cong., Ist Sess. (1943) Vol. 2, pp. 1039-1043. 
are entitled, in order to commence the running of the period of limitation after which its contracts cannot be renegotiated.

The Joint Board thus created is composed of the Chairmen of the Price Adjustment Boards of the War, Navy, and Treasury Departments, the Maritime Commission and the Reconstruction Finance Corporation together with a representative of the Chairman of the War Production Board. The establishment of the Joint Board provided a formal procedure in place of the informal cooperation which had been maintained between the several Price Adjustment Boards and the Secretaries in such matters.

Uniformity of approach by the Departments and by various Services and District Boards is fostered and maintained in numerous other ways. Occasional coordination meetings are conducted by the War Department Price Adjustment Board at which all of the Army Technical Services and Army Air Forces are represented. Problems are there discussed, and the Services are kept informed of any new developments in matter of policy or procedure. In turn, the Services communicate to the District Boards all matters which may have any substantial bearing upon the conduct of renegotiation. The War Department Price Adjustment Board from time to time furnishes to the Services instructions and informative material helpful in maintaining uniformity, and the Field Operations Branch of the Renegotiation Division operates to evaluate and check the renegotiation activities of the Technical Services and Army Air Forces as to organization, procedures and personnel and assists the field sections in obtaining and training competent staffs. Members of the Board and of the Staff visit the various District Boards and Sections, while representatives or members of District Boards and Sections likewise frequently confer with the representatives of the War Department Board.

Periodically, every two or three months, there have been held in different cities joint three-day conferences attended by representatives of all the Departmental Boards and by members of the Price Adjustment Sections of the Army Service Forces and of the Army Air Forces and by Board and Staff members of the District Price Adjustment Boards of the Services and of the Army Air Forces. At these meetings price adjustment problems were discussed, illustrative renegotiations conducted, and every means taken to make uniform the understanding and application of the principles and basis of approach in renegotiation among all of those engaged in the administration of the law. A complete record has been taken of important portions of the proceedings and copies distributed to all of the personnel engaged in the work of renegotiation.

Uniformity has likewise been maintained in War Department renegotiations through the review of all War Department cases by the Settlement Branch of the War Department Renegotiation Division. Every case, whether or not within the scope of the delegation of authority to the Services, is reviewed both by the Financial Review Section and by the Legal Review Section of the Settlement Branch. 
An analysis and report of each case is made to the Board and consideration is given to any unusual circumstance or to any departure from established policies. If the settlement is not in absolute accord with the policies of the Board, the case, unless within the scope of the delegation of final authority to the Services, is either sent back to the Services for further action or the Board itself may assume jurisdiction to complete the renegotiation. Such action may be taken irrespective of whether it will result in a larger or a smaller recovery, as the Board conceives it to be its duty to administer the law with the same fairness of approach to the contractor as to the Government. If the case is one within the delegation to the Services, then any deviation from the principles established by the Board is at once called to the attention of the Service, and the Service takes such corrective steps as may be necessary to insure uniformity in the future.

As a further element in coordination, special and detailed industry studies have been or are being made, as, for instance, in the brass, steel, textile, rubber and machine tool industries. These studies, completed by experts in the respective fields, make available to the Price Adjustment Boards and to the Services precise and informative data of the utmost significance in renegotiation. The renegotiations of contractors in these, as in other industries, are as nearly as possible conducted by the Department or Service which has the greatest familiarity with the industry involved.

Against the background of the general procedures above discussed, the organization and procedure of the different Departments, Agencies, and Services can now be reviewed.

\section{Departmental Organization and Procedures}

\section{War Department}

Army Air Forces. Renegotiation functions in the Army Air Forces are performed in the Office of the Assistant Chief of the Air Staff, Materiel, Maintenance and Distribution and in the Materiel Command.

The Assistant Chief of the Air Staff, Materiel, Maintenance and Distribution has delegated authority for the supervision of the principles and procedures in renegotiation to the Control Officer. The staff in the Control Office for renegotiation is the Price Adjustment Branch. The Price Adjustment Branch, located in Washington, reviews and submits to the War Department Price Adjustment Board for approval, cases renegotiated in the District Offices. It also performs a liaison function with the Board and a service function for the Army Air Forces Price Adjustment Sections with the Board, the Technical Services, Army Service Forces and the other Departments of the Government engaged in renegotiation. The Price Adjustment Branch, Control Office, conducts renegotiation only in exceptional cases and in those cases where an impasse has been reached in the District Offices.

The organization of Price Adjustment activities within the Materiel Command is in accordance with the general organization of the Materiel Command for pro- 
curement purposes. The headquarters office for renegotiation operations in the Materiel Command is the Price Adjustment Office, Wright Field, Dayton, Ohio. This office coordinates the functions of the field offices and all cases are cleared through the Price Adjustment Office, Wright Field to the Price Adjustment Branch, Control Office, Materiel, Maintenance and Distribution. The Price Adjustment Office, Wright Field, maintains all records and statistics and maintains close liaison with other activities of the Materiel Command, particularly the Procurement Division and the Budget and Fiscal Office. Assignments of cases to the District Offices are made by this office. Renegotiation is conducted by this office in a limited number of cases.

Price Adjustment Sections are established in five of the six Procurement Districts of the Materiel Command to conduct renegotiation with contractors within the area of each such Procurement District. ${ }^{7}$

Each District Price Adjustment Section is headed by a Price Adjustment Officer. There is a Price Adjustment Board in each of the Price Adjustment Sections. While membership on the Board varies, the Chief of each Section is a member along with several other civilian or military members.

Each District Office has a staff of negotiators and a separate Cost Analysis Section. In addition, there is usually a Review Section and a Legal Section whose functions are to perfect the Reports and Agreements as initially prepared by the renegotiator.

As of September 13 , r943, the total personnel engaged in renegotiation in the Air Corps was 390 , with I 3 I of this number assisting in a clerical capacity.

The procedures outlined by the Price Adjustment Board are generally followed in the conduct of renegotiation in the Army Air Forces. However, the organization for renegotiation is not rigid and each District Office is organized along the lines best suited for its functioning in view of the personnel available, office space, geographical location and other pertinent facts.

All dealings with the War Department Price Adjustment Board are had through the Price Adjustment Branch, Control Office, Office of the Assistant Chief of the Air Staff, Materiel, Maintenance and Distribution, with one exception. Assignments are forwarded direct from the War Department Price Adjustment Board to the Price Adjustment Office, Materiel Command, which reassigns the case to the appropriate District Office for renegotiation.

Through procedures established by the District Office, the companies are assigned to Renegotiation Panels which consist of two or three negotiators. One of the members of such a panel is primarily responsible for the completion of renegotiation with the company. The negotiator to whom the case is assigned has discretion in handling the case and in arranging for the renegotiation meetings. It is the policy of the Army Air Forces to visit the plant of each contractor and if possible,

\footnotetext{
${ }^{7}$ New York, Detroit, Chicago, Wichita, and Los Angeles, for their respective Procurement District. Area Offices at Cleveland, Cincinnati.
} 
to hold one renegotiation meeting at the contractor's office. The negotiator submits the case to the District Board for consideration prior to the submission of a proposal to the contractor and the approval of the Board is then obtained. If an agreement is reached the Renegotiator and Cost Analyst prepare the report in conjunction with the Review Section and the case is then forwarded through Wright Field to the Price Adjustment Branch, Control Office, Materiel, Maintenance and Distribution for submission to the Board.

If the negotiator cannot secure a settlement, the case is reviewed by the District Board and the contractor is afforded an opportunity to appear before the Board. In the event of a further impasse the record is completed, the contractor's objections obtained and the case is forwarded for further action to (I) Wright Field, (2) the Price Adjustment Branch, Control Office, or (3) the War Department Price Adjustment Board.

The District Offices are about to approve settlements finally under delegation. Since delegation has not heretofore been exercised, the proposed procedure is not in full operation. The authority to approve agreements with contractors having sales not in excess of $\$ 5,000,000$ for the period under renegotiation has been delegated to the District Supervisors of the Procurement District within which the Price Adjustment Sections are located. At the present date, no redelegation has been made by the Assistant Chief of the Air Staff, Materiel, Maintenance and Distribution, of the authority to approve cases finally with contractors having sales in excess of $\$ 5,000,000$ but not in excess of $\$ 10,000,000$ for the period under renegotiation.

Chemical Warfare. Renegotiation in the Chemical Warfare Service is conducted through a Price Adjustment Section located at Baltimore. This Section has been organized as a part of the Purchase Policies Branch in the Office of the Chief, Chemical Warfare Service, and reports directly to the Assistant Chief, Chemical Warfare Service for Materiel.

The Cost Analysis Section has been combined with the Price Adjustment Section and the combined sections are organized on the basis of four panels and a Docket and Assignment Unit, operating under the administrative control of the Section Board. One panel handles general cases, while the other three conduct renegotiations on the basis of geographical location, covering cases in the Chicago, Pittsburgh and New York Procurement Districts.

As of September I, I943, authority was issued for a staff of 20 officers and 35 civilians, and as of September 13, 1943, the four panels embraced a technical personnel of 18 .

The procedures outlined in the Renegotiation Manual are followed. Cases assigned to this Service are first handled by the Docket and Assignment Unit which has the responsibility for obtaining the initial information from the contractor. On the basis of this preliminary information, the company is assigned to one of the panels, depending upon the geographical location of the company's records and home office. 
The first meeting is arranged and conducted by the panel itself. In order to expedite processing of pending cases, the panel spends several days each month in the New York, Chicago or Pittsburgh District office, as the case may be, for the dual purpose of establishing closer contact with the Procurement Districts and permitting closer control over the progress of the contractors in preparing and submitting information required for renegotiations.

While all cases handled through September have been submitted to the War Department Board for approval, it is anticipated that the Service will soon exercise its authority to enter into final agreements.

Engineers. Statutory renegotiations are carried out in the Corps of Engineers under the jurisdiction of the Chief of Engineers, who has designated the Price Adjustment Section in the Office of the Chief of Engineers to supervise and coordinate price adjustment activities of the Division Engineers throughout the continental United States.

The Price Adjustment Section in the Office of the Chief of Engineers consists of five units under the direction of the Chief of the Section: the Advisory Board, the Assignment and Distribution Unit, the Cost Analysis Unit, the Legal Unit and a Renegotiation Unit consisting of a group of sub-units. Primary duties of these units are as follows:

The Advisory Board, consisting of a few men of outstanding ability and experience, reviews reports of renegotiation of Division Price Adjustment Sections in cases in which it is incumbent upon the Chief of Engineers to make such reviews, recommends the basis of settlement in each case renegotiated in the Office of the Chief of Engineers and furnishes expert advice on particular matters referred to it.

The Assignment and Distribution Unit handles all matters dealing with the assignment of contractors for renegotiation and the distribution of agreements and clearance notices in conclusion of renegotiation.

The Cost Analysis Unit procures and analyses financial and factual data in the case of contractors assigned for renegotiation in the Office of the Chief of Engineers and prepares a written report embodying its findings prior to the actual renegotiations. In addition, it furnishes expert advice in cost-analysis matters and assists the field sections in these same matters.

The Legal Unit reviews for legal correctness the agreements and clearance notices including renegotiations, prepares instructions for promulgation within the Engineer Department on policy and procedural matters and handles correspondence and furnishes expert advice in regard to such matters.

The Renegotiation Unit is actually a group of units established for two purposes: (I) for liaison with and assistance to field price adjustment sections in certain geographical jurisdictions and (2) for statutory renegotiations within the Office of the Chief of Engineers.

General administrative and personnel matters are under the control of the Executive Officer of the Price Adjustment Section. 
Division Price Adjustment Sections, patterned in organization generally after the Price Adjustment Section of the Office of the Chief of Engineers, are located in various cities for the different divisions. ${ }^{8}$

The total staff engaged in renegotiation in this Service as of September 13, 1943, was 585 , with $3^{\mathrm{I}} 4$ of this number in a clerical capacity.

The basis of renegotiation of supply contracts, in the Engineers Department, is exactly the same as in the other Services; however, the Corps of Engineers has a very different method of renegotiation in the cases constituting 80 per cent of its case load, i.e., construction cases. In these instances, renegotiation within the scope of a special delegation of authority may be conducted on a separate or group contract basis or on an over-all-profits basis just like supply contracts. The separate or group contract bases have been evolved to fit the peculiar needs of the construction industry and are designed to relieve the contractor of doubt as to his obligations in the face of renegotiation at the earliest possible moment following completion of a contract, in order that his bank credit and bonding capacity can be maintained at a maximum.

Assignment of construction cases to Division Price Adjustment Sections is made to the section having jurisdiction over the area where the major amount of contract work has been done. In the case of supply contracts, assignment is made to the Division section having jurisdiction over the area in which the contractor's home office is located. The Price Adjustment Section of the Office of the Chief of Engineers retains for renegotiation only those cases where exceptional dollar volume, scandalous profits or unusual policy matters may be involved.

Negotiators in the Office of the Chief of Engineers are responsible for the conduct and completion of renegotiation in their respective assigned cases. The general procedure in such cases entails initial advice to the contractor of the renegotiation, meeting of cost analysts with the contractor for the solicitation of financial and factual data, the request to the Cost Analysis Unit for its report, the study and analysis of the cost analysis report, the meeting with the Advisory Board and participation as a voting member in determining the proposed basis for settlement, the renegotiation meetings with the contractor, the writing of the report of renegotiation and procurement of the executed agreement and the final submission of the case to higher authority.

In addition, negotiators in the Office of the Chief of Engineers maintain liaison with Division Price Adjustment Sections to insure the proper handling by the latter of their cases. In cases renegotiated by Division Price Adjustment Sections, where under procedural rules it is incumbent upon the Office of the Chief of Engineers to approve or disapprove the settlement, the negotiator in the Office of the Chief of Engineers reviews the case in detail and participates as a voting member of the Advisory Board in. its over-all review of the case. The negotiator then trans-

\footnotetext{
${ }^{8}$ Boston, New York, Baltimore, Atlanta, Columbus, Chicago, Omaha, Dallas, San Francisco. Also a sub-office in Portland, Oregon.
} 
mits the case for action by higher authority if the case is approved or instructs the field as need be if the case is disapproved.

Authority for the execution of agreements and issuance of clearance notices has been decentralized to Division Engineers so that approximately 90 per cent of all cases assigned to Division Price Adjustment Sections are fully concluded by those sections.

Ordnance. In order to carry out the responsibilities of the Ordnance Department with respect to renegotiation, there was established within the Legal Branch, Purchase Policy Section, Office of the Chief of Ordnance, a Price Adjustment Unit, and Price Adjustment Section Boards have been established in each of the thirteen Ordnance districts. The Price Adjustment Unit at Washington operates as the coordinating agency for the procedures and policies of the thirteen Boards and as the liaison between these Boards and the War Department Price Adjustment Board.

The functions of each District Board are to conduct or supervise renegotiations with contractors assigned to them by the War Department Renegotiation Division through the Office of the Chief of Ordnance. Conforming with policies established by the Chief of Ordnance and in accordance with the judgment of the District Board where policy is not prescribed, renegotiations may be conducted by either the full Board, by individual members thereof or by negotiators delegated by the Board, provided, however, that all settlements are concurred in by a majority of a panel of three of the Board. A Board usually consists of three members, who are representative citizens and outstanding in the business life of their respective communities.

Each Board is assisted by an administrative unit, comprising such negotiators, analysts, technical and clerical assistants as may be required and by the services of a cost analysis unit established in the Ordnance district office for this express purpose. These staffs, handling the detailed work of financial analysis and preparation of reports and agreements during the course of renegotiation, are composed of experienced business men, accountants, financial analysts and attorneys.

The locations of the thirteen Ordnance Price Adjustment Section Boards are as follows: Birmingham, Boston, Chicago, Cincinnati, Cleveland, Detroit, New York, Philadelphia, Pittsburgh, Rochester, St. Louis, San Francisco, and Springfield, Massachusetts. As of September I3, I943, the total personnel of these Boards was 372 , including $24 \mathrm{I}$ technical specialists and I3I clerical assistants.

Renegotiation procedure follows the established pattern. Upon assignment, the Ordnance District Price Adjustment Section Board contacts the contractor requestting the submission of the necessary financial information. The negotiator, handling the case, familiarizes himself with all the pertinent facts and holds the initial conference with the representatives of the contractor. Following this meeting the staff of the District Board analyzes the facts and prepares a full narrative report for the guidance of the negotiator and the Board. On the basis of this report, 
further negotiations either by correspondence, personal call or Board meetings take place until an agreement is reached.

Quartermaster. The Quartermaster Corps Price Adjustment Section is now. known as the Renegotiation Branch of the Pröcurement Division in the Office of the Quartermaster General. The Quartermaster General has delegated authority to conclude final renegotiation agreements with contractors whose total sales are not over $\$ 5,000,000$.

Operations are decentralized with five field offices functioning under the administrative control of the Washington office. New York is the chief operating district office and exercises administrative control also over the other district offices at Boston, Chicago, San Francisco and Greenville, South Carolina. In addition to handling the renegotiation of contractors local to its area, the New York office controls the routing of cases to the other district offices and assists these offices in their renegotiation functions.

In its staff functions, the Washington office supervises the organization and personnel of the district offices and interprets for the Quartermaster Corps the principles, policies and procedures prescribed by the Renegotiation Division for the conduct of renegotiation. Washington also forwards cases received from the Assignment Branch of the Renegotiation Division to the New York office for renegotiation, reviews agreements concluded by the District offices before submission to the proper authority for approval, processes all cases and handles the renegotiation of impasse cases.

As of September 13 , I943; a total personnel of 187 were engaged in renegotiation in the Office of the Quartermaster General, I06 in the capacity of technical specialists and $8 \mathrm{I}$ as clerical assistants.

Cases received by the Washington Office are forwarded to the New York Section and, thence, if necessary, to a district office for renegotiation. A case is assigned to one or two negotiators for handling and the negotiator has the responsibility of supervising the renegotiation procedure, of conducting the conferences with the contractor and recommending the settlement. The negotiator is assisted by other staff members in financial analysis and report writing. All meetings are held at the district offices. In the event of a settlement in a district office, the case is returned to Washington for review and processing of the final agreement. If the field office is unable to conclude an agreement, the case is referred to a panel in Washington for further renegotiation.

Signal Corps. The Price Adjustment Section of the Signal Corps is established as a section of the Purchases Branch of the Procurement Division in the Office of the Chief Signal Officer. Headquarters are in Washington and two field Price Adjustment Sections in Philadelphia and Chicago function as subsidiary offices to Washington, all operating directly under the Chief Signal Officer. The Chief Signal Officer has redelegated authority to the Director of the Procurement Division to conclude agreements with contractors whose total contracts are not over $\$ 5,000,000$. 
The Cost Analysis Branch is under the Fiscal Division and serves both the Contracting Office and the Price Adjustment Section.

The Washington office supervises matters of policies, procedures and operations for all three offices, handles impasse cases for the Signal Corps and conducts negotiations itself on the West Coast. The field offices handle renegotiations assigned to them as coming within their jurisdiction. The chief negotiator and supervisor in Washington operate as an informal board, either or both of them sitting in with the negotiator on all cases assigned to the Washington office as well as on appeal cases from the field offices. The staff handling renegotiation in the Signal Corps includes negotiators, accountants, legal advisors, an engineer and clerical assistants. The clerical personnel of the Washington office handles all routine functions and correspondence as well as the distribution and processing details for all three offices.

As of September I3, I943, the staff embraced a total of 42; of this number 22 were serving in a technical capacity.

Signal Corps procedure differs in certain respects from that of the other Services. Original contacts with a contractor must be conducted through one of the fifty Plant Agents, acting as liaison, operating in zones throughout the country. It is the Plant Agent's duty to make the initial contact, advise the contractor of the type of information, financial and otherwise, that will be required by the cost analyst and negotiator, arrange for obtaining directly or through the company's accountant the necessary financial information and arrange an initial meeting.

An attempt is made to obtain all necessary information prior to holding the first meeting with the representatives of the company. On assignment of the case to the Signal Corps, the Cost Analysis Branch, operating through the Plant Agent, obtains on a prepared form, as soon as possible, a summary of pertinent financial information. After the contractor has assembled the necessary information, a meeting is arranged at the Section office or representatives of the Cost Analysis Branch and Price Adjustment Section call at the contractor's office. Individual cases are assigned to specific negotiators whose responsibility it is to see that the cases are handled expeditiously and to carry through on a case until it is in form for the final renegotiation meeting, at which time an additional senior negotiator is present. The Price Adjustment Section- and Cost Analysis Branch cooperate throughout and a cost analyst is present at all meetings with the contractor.

Surgeon General. The Renegotiation Division is established in the Supply Service, Office of the Surgeon General, with headquarters in Washington and field branches located in New York and Chicago. The Surgeon General has appointed, and delegated authority, for the conduct of renegotiation to the Director of the Division and has appointed a Review Board of five members, including the Director, to pass upon proposed agreements, prior to their submission for signature either to the Division Director or to the Surgeon General, or the War Department Price Adjustment Board. Recognizing the importance of close cooperation between renegotiation and procurement activities, close liaison in operations is maintained 
between the Procurement Division, the Renegotiation Division, and the Commanding Officer of the Army Medical Purchasing Office.

The Director of the Division has appointed a Chief in the Washington Office and a Chief in charge of the New York and Chicago branch offices to supervise renegotiations under their jurisdiction, and, in turn, they have, with the approval of the Director, organized the necessary staffs, including negotiators and cost analysts, to carry out their functions. The negotiator has complete responsibility for the prompt and final disposition of all cases assigned to him. In carrying out this assignment, he arranges for an initial conference with the contractor, attended jointly by himself and the cost analyst; gathers with the assistance of the cost analyst all essential information from any source available; conducts further renegotiation meetings; is responsible for minutes of procedure; prepares standard reports with the cooperation of the cost analyst, and final agreements, and expedites processing of each case through the Review Board to the end that the final agreement is forwarded to the contractor as soon as possible. The cost analyst is charged with the procurement, analysis and reporting on proper forms and reports of all necessary accounting information. The chief of the Renegotiation Branch advises the negotiator, and the Chief of the Cost Analysis Branch of the Washington office counsels with the cost analyst on all matters of procedure.

The total personnel, as of September 13, r943, engaged in renegotiation work in the Surgeon General's Office was 32, including 22 technical representatives and ro clerical assistants.

All dealings with the War Department Price Adjustment Board are handled directly with the Washington office of the Renegotiation Division, and all assignments from the Board go directly to the Washington office. The Washington office sends out the initial letter requesting data and continues as contact with the contractor until it is possible to determine the nature of the case and whether it is appropriate to hold the preliminary meeting with the company. Where called for, cases are assigned by Washington to the New York or Chicago Branch and the Chief of each field branch, guided by instructions from the Director of the Division, assigns the case to a team of two, consisting of representatives of the Renegotiation and Cost Analysis Sections. At this time, the company is notified of the transfer and directed to correspond with the appropriate field branch. Certain cases are retained for renegotiation by the Washington office.

Subject to the supervision of the Chief of the field branch, the negotiator to whom the case is assigned has complete discretion in handling the case and in calling the preliminary conference. Immediately following the meeting the minutes of the proceedings are drawn up and sent directly to the Washington office. The negotiation team then prepares a tentative report of renegotiation and obtains approval of the Chief of the branch and of at least two members of the Review Board as to any proposed basis of settlement prior to the final conference with the company. Where an agreement is reached, the negotiator and cost analyst com- 
plete their report on all aspects of the case and submit it to the Washington office together with copies of the final agreement.

No agreement is sent to the contractor for execution until it has been approved by a member of the Review Board. Where the agreement involves any substantial departure from the form prescribed by the War Department Price Adjustment Board, and/or where it involves any new and unusual provisions, it is submitted to at least two other members of the Review Board before it is sent to the contractor for execution. To assist the field office, representatives from Washington regularly visit the field offices. All processing and distribution of the final reports and agreements are performed by the Washington office.

The Surgeon General has redelegated to the Renegotiation Division Director power to enter into final and other agreements with contractors whose total sales do not exceed $\$ 5,000,000$. The Review Board has been granted the authority to pass on all agreements, and unanimous approval by the Board is required before submission to the Director or Surgeon General for signature. Cases in which the final agreement is not unanimously approved by the Board are either referred back to the Division for further negotiations or to the War Department Price Adjustment Board for final action.

Transportation. Renegotiation in the Transportation Corps is conducted from a central office in Washington. Control of this function has been delegated to the Chief of the Fiscal Division. Flexible in operation, two key men function informally as final authority on matters of review, instead of a formal board, and the Chief of the Fiscal Division has the power to sign agreements recommended by this panel.

To accomplish decentralized operation and accommodate the convenience of the contractor, the Transportation Price Adjustment Section has located in each of the nine transportation zones one or two junior officers, trained in renegotiation procedure, able to undertake the necessary accounting work with a contractor and to assist in the determination of the amounts of business properly subject to renegotiation and the breakdown of costs applicable to renegotiable business. Assisting these representatives, the Washington office uses teams of negotiators in cities adjacent to the offices of the contractors where it is impractical for these contractors to come to Washington. The customary procedure in preparing the necessary case histories and financial analysis of renegotiable business is followed.

As of September 13, I943, the personnel of this Section totaled 28, including 2 men in charge of operations, 2 other negotiators, 4 cost analysts operating within the office and 16 other accountants located in the Procurement Districts throughout the country devoting part time to renegotiation.

\section{Navy Department Price Adjustment Board}

The Under Secretary of the Navy has established a Price Adjustment Board with Divisions at New York and Washington and Regional Price Adjustment 
Boards at Chicago and San Francisco to conduct the renegotiations of contracts pursuant to the Act. These Boards have been created in the Office of Procurement and Material under the supervision of the Assistant Chief in Charge of Procurement.

The Navy Department Price Adjustment Board in Washington determines all questions of policy and procedure, with the approval of the Under Secretary of the Navy and conducts actual renegotiation with contractors. The New York office and the Regional Boards conduct the renegotiation proceedings of contractors in their regions. The main office of the Board in Washington has seven Board members, including the Chairman and Executive Vice Chairman, while six other Board members, operating under a Vice Chairman, are located in New York City. Operating under regional Chairmen, the Chicago Board has five members and the San Francisco Board has four members.

Following the policy of employing only the most highly trained personnel with practical experience in the phase of work for which they are engaged, all Board members are experienced professional and business men, practically all of the accountants are Certified Public Accountants and the analysts are experienced in financial work. As of August 3r, I943, the personnel of all four Boards totaled I8I, including 22 Board members, 23 other contract employees, 72 officers and 64 Civil Service employees. In addition, the Navy utilizes some 150 panel auditorspartners or senior employees of leading accounting firms throughout the United States who have agreed to lend their services on a per diem basis, when required, to assist the contractors in preparing factual material needed by the Board.

The Navy has made every effort to simplify the procedures of renegotiation so as not to place any undue burden on contractors. Names of all contractors and subcontractors engaged in war work are obtained through the joint Assignment Section of the Departmental Price Adjustment Boards from various governmental agencies or other sources of information including the income tax returns of corporations. Where there is a possibility of the existence of excessive profits requiring renegotiation, the "Preliminary Letter of Information" is sent to the contractor requesting current data, including balance sheets and profit and loss accounts, a breakdown between renegotiable and non-renegotiable business and the total business done with each governmental Department and Agency. Upon the basis of this information, a case in which the Navy Department has the predominant interest is assigned to the Navy Department Price Adjustment Board.

Accountants and analysts of the Board study these data and supplement them with other sources of information and by contacting the procurement officers of the governmental Departments and Agencies doing business with the contractor. A preliminary report is then prepared for consideration by the Board and, if it is apparent that no excessive profits exist, the Board immediately gives the contractor a clearance, notifying the company accordingly by letter. 
If, on the other hand, there may be excessive profits, several procedures may be followed. The case may be referred to a panel auditor or to one of the Board's own accountants who calls upon the contractor and assists him in preparing further factual information desired by the Board.

If the amount involved is relatively small, the case may be handled through so-called field renegotiation whereby the Board assigns the case to one of its own accountants and analysts to call on the contractor, develop the necessary additional information and endeavor to arrive at a mutually satisfactory agreement regarding any excessive profits. If an agreement is reached in the field, it is submitted to the Washington Board for consideration and approval, and the contractor is further advised of his right, if he prefers to do so, of appearing before one of the Boards.

In a number of cases, however, the contractor appears before the Board. The analyst and an accountant prepare a complete report and the contractor is encouraged to develop whatever further facts he may wish the Board to take into consideration. At the Board meeting, attended by the company's representatives and by the Board members, the analyst and accountant as well as contracting officers and representatives from the technical bureaus familiar with the material produced and with the company's performance, a full discussion of all phases of the company's war work, earnings and costs is held. If an agreement is reached as to the proper settlement, a contract is prepared and submitted for approval to the Under Secretary of the Navy who is also sent a summary of the facts of the case. If no agreement can be reached the facts are submitted to the Under Secretary of Navy for such action as he may take.

\section{Maritime Commission}

The Price Adjustment Board of the Maritime Commission was created by action of the Commission embraced in Administrative Order No. 64 and to this Board the Chairman of the Maritime Commission delegated the powers and duties conferred upon him under the Act.

The Board located in Washington is comprised of four members, a member of the Maritime Commission serving as Chairman, a Naval officer who is in active charge of all of its operations, the counsel of the Board and the representative of the War Production Board.

As of October I, 1943, there was a total personnel of 40 , including the Board members, I3 renegotiators, 15 accountants and 9 stenographers.

Cases assigned to the Maritime Commission Price Adjustment Board are in turn assigned to individual renegotiators who have charge of the preparation of the individual company cases. The renegotiator is assisted in the actual renegotiation by an additional renegotiator so that at all times there are at least two renegotiators, together with a member of the analyst section, acting at the renegotiation conference with the company. 
In the preparation of a case the Board relies to a large extent on certified audits furnished by the contractor. As contrasted with the procedure of the War and Navy Departments, the Board does not have any established field auditing system and does not utilize a field auditor except in an exceptional case when Maritime Commission field auditors are employed.

After conferences with the contractor have been held, the renegotiators present the facts to the Board, which arrives at a decision as to the amount of excess profits, if any. Contracts or clearance letters are then drawn and are approved by the Commission and signed by the Chairman.

\section{War Shipping Administration}

Executive Order 9054, dated February 7, I942, created the War Shipping Administration, delegating to it certain of the functions previously exercised by the Maritime Commission. Following the passage of the Renegotiation Act, the Order was amended on September 16, 1942, by Executive Order 9244 to specifically delegate appropriate powers of renegotiation, conferred upon the Maritime Commission under the statute, to the War Shipping Administration. In conformance with this authority the War Shipping Administrator on February 12, r943, created the Price Adjustment Board within the War Shipping Administration and charged the Board with the responsibility of renegotiation.

The Administrator has appointed a Board of five members and a Chairman of the Board to supervise renegotiation procedure. The Board is composed of the Chairman, the General Counsel of the War Shipping Administration, the War Production Board representative and two other members. The office of the Board has been established in New York City as this location is in closest proximity to the great majority of War Shipping contractors and furnishes the best market for the specialized personnel required for this work.

In contrast to the other agencies engaged in renegotiation, the War Shipping Board is engaged primarily in the renegotiation of contracts for the rendition of services. As the result of the special problems involved in repairing, chartering, stevedoring and operating of vessels, specialized experience and background is required, and much of the time of this Board to date has been devoted to securing the necessary capable personnel versed in the marine industry. At present this Board has assembled a small but well-qualified staff, which is assisted by members of the Auditing Department of the Administration who are located in New York City and in the various yards.

General operations in the conduct of renegotiation follow the pattern of the War Department Manual for Renegotiation. Assignments are received through the Joint Departmental Assignment Board, the necessary information is obtained, and renegotiations are conducted to the end either of a clearance or a mutual agreement as to the amount of excessive profits which have been or may be realized. A comprehensive survey of the stevedore trade was completed to determine the profits existing in various areas before renegotiation of a single stevedore was attempted. 
The War Shipping Administration makes considerable use of a contractual recapture clause wherein a contractor agrees to refund all profits in excess of to per cent. As a consequence, it is necessary for their auditors to make an audit of War Shipping contracts so that the monies due under this clause may be recaptured prior to commencement of renegotiation procedure. For this reason and because the contractors in this field, dealing largely with labor, are even more deluged than manufacturers with demands for figures and reports, the conduct of renegotiation has been considerably delayed.

\section{Treasury Department}

Authority for renegotiation in the Treasury Department was redelegated by the Secretary of Treasury to the Director of Procurement. The Director was empowered to act for the Secretary in the establishment of the necessary organization and in approving renegotiation agreements. Accordingly the Director of Procurement established the Treasury Department Price Adjustment Board, appointed the Chairman and the other members of the Board, and authorized the Chairman to select the operating staff.

The Board is comprised of the Chairman, the representative of the War Production Board and three other members, in addition to legal counsel who attends in an advisory capacity. There is also an operating staff of II analysts, the majority being either Certified Public Accountants or chartered accountants, and a clerical force of r2. At this date the Board functions only in Washington, no renegotiations having been conducted in the field.

The procedures for renegotiation in the Treasury Department have been patterned after those of the War Department. Following assignment, an analyst gathers the necessary information and prepares the preliminary report for review by the Board prior to conferences between the Board and the contractor. The final report, upon approval by the Board, is prepared by a Board member for the signature of the Director of Procurement.

\section{Reconstruction Finance Corporation}

The four subsidiaries of the Reconstruction Finance Corporation handling war purchases-namely, Defense Plant Corporation, Metals Reserve Company, Defense Supplies Corporation and Rubber Reserve Company-were brought within the purview of the Act by amendment dated July I, x943. The Boards of Directors of these companies delegated all their authority under the Act to one central Board in Washington. Comprised of five members, including an appointed chairman and the heads of each of these companies, the Reconstruction Finance Corporation Price Adjustment Board handles renegotiation for all these agencies.

The Board alone has the power of final determination. A Reviewing Committee of three members has been created by the Board to conduct the actual work of renegotiation. While this Committee does not as yet have the power of final determination, it carries the full authority of the Board in other matters. A staff 
of negotiators, cost analysts and legal personnel is being formed to handle the usual detailed functions and to confer with contractors.

In forming its organization, the Board called in representatives from ir of the Reconstruction Finance Corporation field offices for training in the principles, policies and procedures of renegotiation. It is proposed that these men will train additional representatives on returning to their districts. It is estimated that the personnel requirement of the Board will reach a total of roo by next July, including 40 negotiators, 30 cost analysts and 30 clerical employees.

Owing to its long experience and established procedures, the Reconstruction Finance Corporation Board anticipates the ability to handle renegotiation on a practical and flexible basis with its negotiators located throughout the country for the convenience of the contractors. On new cases, these representatives will obtain information in the field, eliminating the need for calling the contractor to Washington. On closed cases, wherein Reconstruction Finance Corporation contracts are similar to the business already renegotiated, the negotiator will be granted limited authority to reach a further settlement on the same basis. Where cases have already been assigned and are not completed, this Board will allow the Department or Service having the assignment to complete the cases with respect also to Reconstruction Finance Corporation business.

\section{ConcLusion}

The task of renegotiation has been difficult. With the passage of the statute, a staggering volume of war contracts became subject to renegotiation and the problem was further complicated by the pressure of time. The Act prescribes that renegotiation proceedings must commence within one year following the close of the fiscal year of the contractor within which completion or termination of a contract occurs. The entire administrative machinery and procedures for renegotiation have been developed since April 28, r942, with the view to performing this work as expeditiously as possible, with maximum fairness to both the Government and war contractors, and to completing the renegotiation of war contracts within the statutory time allowed.

In the short space of one year and a half, the pioneering work of organization, of formulation of principles, policies and procedures and of renegotiation of a substantial volume of war contracts has been completed. As the result of able administration and the splendid cooperation of American industry, the work has progressed satisfactorily in the face of innumerable problems and of the expressed opinion in certain quarters that renegotiation would take one hundred years and was impossible.

The assignment of 1942 business for renegotiation has been practically completed. After reviewing the large majority of possible renegotiation cases and withholding from assignment many thousands of companies as not being subject 
to renegotiation on their I942 business, the Clearance and Assignment Officer, as of October I, I943, had assigned 20,457 cases for renegotiation. ${ }^{9}$

With each Department and Service gearing its organization and machinery to effect substantial completion of the renegotiation of 1942 business by the end of I943, the work of actual renegotiation is now in full swing. While there are variations in the rate of production between the various agencies, progress throughout the field of renegotiation has been satisfactory. As of October I, I943, agreements have been reached in over 40 per cent of the total number of cases assigned, these cases representing by far the bulk of $\mathrm{r} 942$ renegotiable business by dollar volume.

The total original dollar amount of the contracts already renegotiated is approximately $\$ 38,000,000,000$, and, on these contracts, commitments for the elimination of excessive profits in the amount of approximately $\$ 4,500,000,000$, have been made as of October I, I943. (It is estimated that of this amount only 70-75 per cent would have eventually accrued to the Government through taxes.) Cash refunds represented around $\$ 2,200,000,000$ and price reductions around $\$ 2,300,000,000$ of this amount.

With the machinery for renegotiation now well established, with personnel selected, indoctrinated and experienced, and with major principles, policies and procedures determined, the price adjustment work is expected to accelerate substantially. From the standpoint of both the Government and industry, renegotiation can henceforth be expected to be completed more expeditiously than during the pioneering days now well behind us.

\section{Addresses of Offices.}

APPENDIX

Price adjustment offices for the various departments, agencies and sections handling renegotiation work are located at the following addresses:

Departmental Price Adjustment Boards: War Department, Room 3D 58r, The

'While not indicative of the dollar volume or amount of work involved, the following table of these assignments reflects to a degree the relative task of the renegotiation agencies:

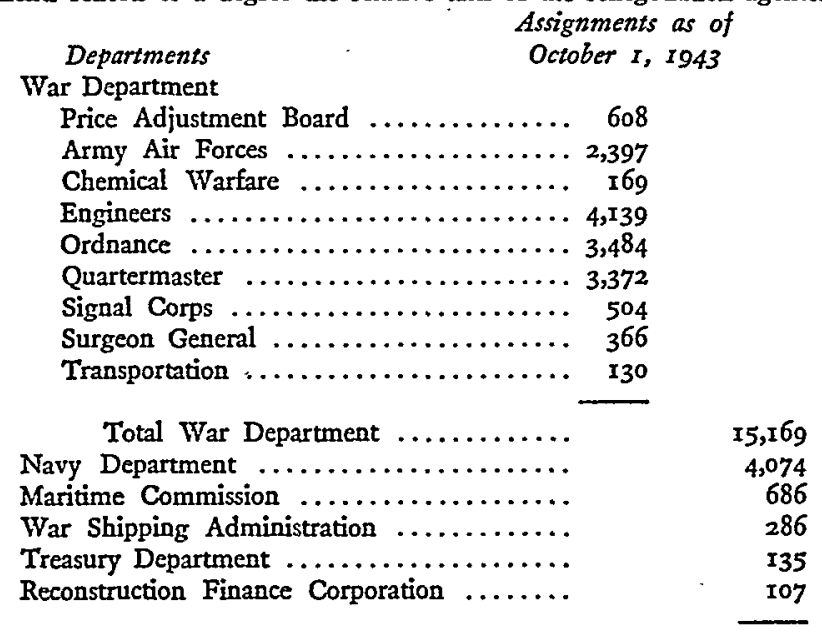


Pentagon, Washington, D. C.; Navy Department, 7x8 I8th Street, N. W., Washington, D. C., $6305^{\text {th }}$ Avenue, Room 310, New York, N. Y., 2xst Floor, roo West Monroe St., Chicago, Ill., 727 Financial Center Building, 405 Montgomery St., San Francisco, California; Maritime Commission, Room 4827, Commerce Building, Washington, D. C.; Treasury, Room 5304, Procurement Building, 7th \& D Streets, S. W., Washington, D. C.; War Shipping Administration, 39 Broadway, New York, N. Y.; Reconstruction Finance Corporation, 8ri Vermont Avenue, N. W., Washington, D. C.

Price Adjustment Sections, War Department: Ordnance, Room ${ }_{4} \mathrm{E}$ 371, The Pentagon, Washington, D. C.; 700 Frank Nelson Building, Birmingham, Alabama; Room I50I, I40 Federal Street, Boston, Mass.; 38 South Dearborn Street, Chicago, Illinois; Big Four Building, Cincinnati, Ohio; roo6 Terminal Tower Building, Cleveland, Ohio; $183_{2}$ National Bank Building, Detroit, Michigan; Room 1815, 80 Broadway, New York, N. Y.; I50 South Broad Street, Philadelphia, Pa.; I202 Chamber of Commerce Building, Pittsburgh, Pa.; I238 Mercantile Building, Rochester, N. Y.; 3663 Lindell Boulevard, St. Louis, Missouri; 402 Hotel Empire, San Francisco, California; 95 State Street, Springfield, Mass.

Quartermaster Corps: Room 2049 Tempo B, and \& Q Streets, S. W., Washington, D. C.; 52x 5th Avenue, New York, N. Y.; I State Street, Boston, Mass.; 333 North Michigan Avenue, Chicago, Illinois; Kohl Building, Montgomery \& California Streets, San Francisco, California; Woodside Búilding, Greenville, South Carolina.

Signal Corps: Room 2C 285, The Pentagon, Washington, D. C.; I North LaSalle Street, Chicago, Illinois; $x 7^{\text {th }}$ \& Sansom Streets, Architects Building, Philadelphia, Pa.

Army Air Forces: Room ${ }_{5}^{\mathrm{E}}$ 1039, The Pentagon, Washington, D. C.; Wright Field, Dayton, Ohio; 67 Broad Street, New York, N. Y.; 420 West Douglas Avenue, Wichita, Kansas; 3636 Beverly Boulevard, Los Angeles, California; Fox Theater

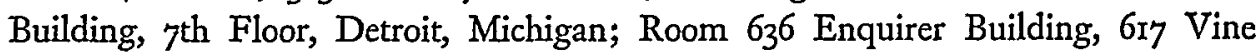
Street, Cincinnati, Ohio; 20 North Wacker Drive, Chicago, Illinois; Room 204, 4900 Euclid Building, Cleveland, Ohio.

Corps of Engineers: Room 5160, New War Building, 21st \& Virginia Avenue, N. W., Washington, D. C.; 605 Lincoln Road, Miami Beach, Florida; 75 Federal Street Building, Boston, Mass.; 27o Broadway, New York, N. Y.; ror E. Fayette Street, Baltimore, Maryland; 50 Whitehall Street, Atlanta, Georgia; Ir2o Huntington Bank Building, Columbus, Ohio; 332 South Michigan Avenue, Chicago, Illinois; III4 Commerce Street, Dallas, Texas; 206 South rgth Street, Omaha, Nebraska; 35I California Street, San Francisco, California.

Surgeon General: Room 4 I9 Maritime Building, I8I8 H Street, N. W., Washington, D. C.; 52 Broadway, New York, N. Y.; I2th \& Spruce Streets, St. Louis, Missouri.

Transportation Corps: Room 3A 674, The Pentagon, Washington, D. C.

Chemical Warfare Service: Butler Building, 200 West Baltimore Street, Baltimore, Maryland. 